\title{
Isolation by differential display of three partial cDNAs potentially coding for proteins from the VA mycorrhizal Glomus intraradices
}

\author{
Gabriele DELP $^{* 1}$, Sally E. SMITH ${ }^{2}$ and Susan J. BARKER ${ }^{1,3}$ \\ ${ }^{1}$ Department of Plant Science and the Centre for Plant Root Symbioses, The University of Adelaide, Waite Campus, Private Bag 1, Glen Osmond, \\ South Australia, 5064, Australia. \\ ${ }^{2}$ Department of Soil Science and the Centre for Plant Root Symbioses, The University of Adelaide, Waite Campus, Private Bag 1, Glen Osmond, \\ South Australia, 5064, Australia. \\ ${ }^{3}$ Plant Sciences, and the Centre for Plant Root Symbioses, The University of Western Australia, Nedlands, Western Australia, 6907, Australia. \\ Accepted 21 May 1999.
}

\begin{abstract}
A molecular study of the mycorrhizal symbiosis between barley and Glomus intraradices used differential display PCR and a synchronous colonization method to identify genes that are differentially expressed in symbiosis. Several PCR products were consistently differentially amplified. PCR amplification of genomic DNA from either G. intraradices or barley as templates showed that three such products were encoded by G. intraradices. Sequence analysis of the deduced amino acid sequences of the fungal fragments, following extension by $3^{\prime}$-RACE, revealed similarities to proteins from higher eukaryotes. One (GINMYC1) shows similarity to TRIP15, a human protein that interacts in a hormone-dependent manner with the thyroid receptor. A second (GINMYC2) is similar to $O$-linked $N$-acetylglucosamine transferases from vertebrates, and the third (GINHB1) contains a putative leucine zipper and a homeodomain which indicates that it binds DNA and may act as a transcriptional regulator. Fragments of the expected sizes were amplified by RT-PCR from mRNA of mycorrhizal barley roots for all three fungal cDNAs, which indicates that the corresponding genes are expressed during intraradical growth of G. intraradices. The results provide a promising insight to fungal gene expression early in formation of this compatible and mutualistic symbiosis.
\end{abstract}

Vesicular arbuscular (VA) mycorrhizas are intimate mutualistic symbioses between the roots of the majority of land plant species and fungi belonging to the Glomales (Zygomycota). Available fossil and molecular evidence supports the concept that this symbiosis is of ancient origin, implying a very long period of co-evolution of plants and fungi with a possible integral part in establishment of a land flora around 450 million years ago (Simon et al., 1993; Remy et al., 1994). Bidirectional nutrient transfer is the main basis for mutualism. The fungi depend on a supply of photosynthate from the plants and at the same time increase uptake of mineral nutrients, particularly phosphorus, from the soil (Harrison, 1997; Smith \& Read, 1997). Hence, both members of the association can benefit, but whereas symbiosis is obligate for the fungi this is not the case for the plants, which vary in their responsiveness to fungal colonization. Very little is known about the molecular and genetic controls of the interaction, in part because of the difficulties of dealing with fungi that cannot complete their life cycles in the absence of the plant. Furthermore, fertilizer-treated crop plants can usually achieve full growth potential in the absence of the fungus, so that the importance of the symbiosis has been obscured by modern agricultural practice (see Smith \& Read, 1997).

* Corresponding author.
We are interested in this symbiosis because the association represents a beneficial, long-term, compatible interaction, with the fungus able to penetrate the plant root and grow inside root cells without inducing any disease symptoms in the plant. Morphogenetic changes in both plant and fungus during colonization indicate that there must be an exchange of signals between the partners, with regulation occurring at several control points (Barker, Tagu \& Delp, 1998). The final outcome is a functional mycorrhizal root, in which metabolic activity in the two symbionts is regulated and presumably under the control of genes of both symbionts. Molecular tools are now beginning to permit investigation of the fungal genome and of gene expression underlying symbiotic function in both fungi and plants.

Identification of genes from VAM fungi has been especially difficult, because of the obligate symbiotic nature of these root-colonizing fungi. Although fungal cDNAs are present in cDNA libraries from mycorrhizal roots, they are not readily identified in differential screens with cDNA probes because of their very low abundance. A gene (Gv1) with homology to a DNA-binding protein from Ustilago maydis has been isolated by differential screening of a cDNA library (Burleigh \& Harrison, 1998). All the other genes that have been cloned from VAM fungi to date, however, were isolated by PCR, either from cDNA synthesized from spore RNA, or by using primers for conserved regions of known genes to screen 
libraries. The transcripts isolated from spore RNA include ribosomal RNA, indicating that the RNA extracted from the spores was of VA mycorrhizal fungal origin, and transcripts with coding sequences similar to glyceraldehyde-3-phosphate dehydrogenase, beta-tubulin and two types of ATPases, indicating the expression of these genes in germinating spores (Franken et al., 1997). By using heterologous probes for transport-related genes, a fungal phosphate transporter (GvPT; Harrison \& van Buuren, 1995) and fungal nitrate reductase genes (Kaldorf, Schmelzer \& Bothe, 1998) have been cloned. These essentially targetted approaches would not, however, have been able to detect the expression of 'unexpected' genes involved in the symbiosis.

The problem of poor representation of fungal cDNAs in libraries can be overcome by using differential display (Liang \& Pardee, 1992), a method in which detection of a cDNA does not depend on its prevalence (Wan et al., 1996), and does not involve preconceived ideas of which genes are likely to be expressed. Differential display has already been used in the analysis of gene expression in mycorrhizal roots (MartinLaurent, Franken \& Gianinazzi, 1995; Vögeli-Lange et al., 1996; Martin-Laurent et al., 1997) and resulted in the isolation of a differentially regulated plant gene from mycorrhizal roots of pea and a partial sequence identified as a fungal $25 \mathrm{~S}$ rRNA gene (Martin-Laurent et al., 1997). No other fungal genes have been identified so far using this technique, but it appears to have great potential to identify fungal genes expressed at different stages of the symbiosis. Here we report the successful application of differential display to identify both plant and fungal genes in mycorrhizal roots and the partial characterization of three fungal cDNAs coding for proteins with potentially regulatory function from the VAM fungus Glomus intraradices in symbiosis with Hordeum vulgare.

\section{MATERIALS AND METHODS}

\section{Growing and inoculating plants}

Surface-sterilized barley (Hordeum vulgare L. cv. Galleon) seeds were germinated on wet filter paper for $3-5 \mathrm{~d}$ until the roots were about $1 \mathrm{~cm}$ long. They were then transplanted to nurse pots containing leek (Allium porrum L.) as host plant and Glomus intraradices N. C. Schenck \& G.S.Sm. as the VA mycorrhizal fungus, following the method described by Rosewarne, Barker \& Smith (1997). Non-mycorrhizal control plants were grown in the same way, except that the leeks in nurse pots were not inoculated. Barley seedlings from mycorrhizal and control pots were washed from the soil at different times after transplanting, roots quickly frozen in liquid nitrogen and stored at $-80^{\circ} \mathrm{C}$ until further use. Colonization of mycorrhizal plants was assessed with the lineintersect method (Giovannetti \& Mosse, 1980) following clearing with $10 \% \mathrm{KOH}$ and staining with trypan blue; a modification of the method of Phillips \& Hayman (1970), omitting phenol from all reagents.

\section{DNA extractions}

DNA of G. intraradices was isolated by the method of Zézé, Dulieu \& Gianinazzi-Pearson (1994) from spores picked from agar plates on which the fungus was grown symbiotically with transformed carrot roots in the absence of any other micro-organisms (Bécard \& Fortin, 1988). DNA extraction from barley leaf tissue was achieved using a DNA mini-prep method adapted from Rogowsky et al. (1991). Approx. $10 \mathrm{~cm}$ of young leaf tissue was ground in liquid nitrogen in a $2 \mathrm{ml}$ centrifuge tube using a knitting needle. The powder was resuspended in $750 \mu \mathrm{l}$ of extraction buffer $(0.1 \mathrm{M}$ Tris- $\mathrm{HCl}$, $\mathrm{pH} 8 / 10 \mathrm{~mm}$ EDTA/0.1 M NaCl/1\% sarkosyl) and immediately mixed with an equal vol. of phenol-chloroform-isoamyl alcohol $(25: 24: 1, \mathrm{v}: \mathrm{v}: \mathrm{v})$, then held on ice until all samples had been processed. Next, the batch was extracted by endover-end rotation (10 $\mathrm{min}$, room temperature), and phases were separated by centrifugation $(5000 \mathrm{rpm}, 5 \mathrm{~min}$, room temperature). The aqueous phase was re-extracted as described above, extracted once with an equal vol. of chloroform, then mixed by inversion after addition of 0.1 vol. of $3 \mathrm{M}$ sodium acetate $\mathrm{pH} 4.8$ and 1 vol. of propan-2-ol. The precipitate was collected by centrifugation ( $14000 \mathrm{rpm}, 15 \mathrm{~min}, 4^{\circ}$ ), the pellet washed briefly in $70 \%$ ethanol, air dried, then resuspended in $50 \mu \mathrm{l}$ of TE buffer (10 mM Tris-HCl/1 mM EDTA, pH 8).

\section{RNA extractions}

Extraction of total RNA from barley roots, DNase treatment of the RNA and mRNA isolation were performed as described previously (Delp, Rosewarne \& Barker, 1998).

\section{Reverse transcription of poly $\left(A^{+}\right) R N A$}

100 ng of poly $\left(\mathrm{A}^{+}\right) \mathrm{RNA}$ were reverse transcribed with either $0.1 \mathrm{\mu g}$ random primer (9mer) or $0.5 \mathrm{\mu g}$ oligo(dT) (15mer, Promega) in a $25 \mu \mathrm{l}$ reaction containing $500 \mu \mathrm{M}$ of each dNTP, $40 \mathrm{U}$ of RNase inhibitor (Promega), and $200 \mathrm{U}$ of reverse transcriptase (Superscript II RNaseH ${ }^{-}$; Gibco-BRL) in the reaction buffer supplied by the manufacturer. The reaction was carried out at $37^{\circ}$ for $60 \mathrm{~min}, 42^{\circ}$ for $30 \mathrm{~min}$ and $95^{\circ}$ for $5 \mathrm{~min}$. 1.5 U of RNase H (Promega) were added and the sample incubated at $37^{\circ}$ for $30 \mathrm{~min}$. The reaction was stored at $-80^{\circ}$ until it was needed for use as template for PCR.

\section{PCR}

All PCRs were carried out in a GeneAmp PCR System 9600 (Perkin-Elmer). Differential display PCR was carried out using the 10mer deoxyoligonucleotides (Bauer et al., 1993) as primers as described by Delp et al. (1998) with the following modifications to cycling conditions due to use of a different thermocycler model: one cycle with $94^{\circ} 5 \mathrm{~min} / 42^{\circ} 2 \mathrm{~min} / 72^{\circ}$ $3 \mathrm{~min}, 45$ cycles with $94^{\circ} 30 \mathrm{~s} / 42^{\circ} \mathrm{Imin} / 72^{\circ} 30 \mathrm{~s}$ and one cycle with $94^{\circ} 30 \mathrm{~s} / 42^{\circ} 1 \mathrm{~min} / 72^{\circ} 5 \mathrm{~min}$. To reamplify bands of interest, a pipette tip was stabbed into the agarose piece showing the band and pipetted up and down several times in a reaction mixture containing the same ingredients and primers as the differential display PCR. Cycling parameters for reamplification were: denaturing step of $4 \mathrm{~min}$ at $94^{\circ}, 35$ cycles with $94^{\circ} 30 \mathrm{~s} / 42^{\circ} 1 \mathrm{~min} / 72^{\circ} 30 \mathrm{~s}$ and a final extension period of $5 \mathrm{~min}$ at $72^{\circ}$. The products were analysed on agarose gels containing $0.2 \mu \mathrm{g} \mathrm{ml}^{-1}$ ethidium bromide and 
bands containing fragments for cloning were cut from the gel under long wavelength uv light.

PCR to determine the genome of origin for differential display products was performed with a dilution series of approx. $50 \mathrm{ng}$ to $0.4 \mathrm{ng}$ G. intraradices DNA or $500 \mathrm{ng}$ to $4 \mathrm{ng}$ barley DNA as template. Specific primers were designed from the sequences of the differential display products. Sequences were: 5'-GATGGGACAGGTGTTGATCT and 5'TATTGATGGTCTTCTCGGAG for Ginmyc1, 5'-GCAACGTTCGCAAATCCCTT and 5'-AGCAGGTGGGCTGTATGATT for Ginhb1, 5'-CATCGGGAACACCTGGAAAT and 5'-AGCAGGAGACCGCAATCACA for Ginmyc2, and 5'AAGCTGGCAGTGAACCTTAT and 5'-AAAGCCTTCCTCCTGAACAT for $d d 1 a$. The reaction volume was $20 \mu \mathrm{l}$, containing $2 \mu \mathrm{l} 10 \times$ Taq polymerase buffer (supplied with enzyme), $1 \mu \mathrm{M}$ each of two fragment-specific primers, $200 \mu \mathrm{M}$ of each dNTP, $2 \mathrm{mM} \mathrm{MgCl}_{2}$, and $0.5 \mathrm{U}$ Taq DNA polymerase (5 $\mathrm{U} \mathrm{ul}^{-1}$; Promega). Cycling conditions were: $4 \mathrm{~min} 94^{\circ}, 40$ cycles with $94^{\circ} 30 \mathrm{~s} / 60^{\circ} 30 \mathrm{~s} / 72^{\circ} 30 \mathrm{~s}$, one cycle with $94^{\circ}$ $30 \mathrm{~s} / 60^{\circ} 30 \mathrm{~s} / 5 \mathrm{~min} 72^{\circ}$.

RT-PCR was performed using $I \mu l$ and $0.1 \mu l$ of RT reactions as template. Reaction conditions and cycling parameters were as for reactions with genomic DNA as template.

\section{Cloning and sequence analysis of PCR products}

Reamplified differential display fragments for cloning were treated with Klenow (Sambrook, Fritsch \& Maniatis, 1989) to ensure that they were blunt ended. They were then cloned into pGEM or pZero plasmid vectors. Positive clones were analysed for presence of the inserts of the correct length, according to Sambrook et al. (1989). Sequencing was performed using a 373A DNA sequencer (Applied Biosystems) and sequence assembly and analysis used SeqED software (Applied Biosystems). Subsequent sequence manipulation and alignment was carried out using Lasergene (DNAStar). Sequences have been deposited in GenBank under the accession nos AF110196, AF110197 and AF110198.

\section{$3^{\prime}-R A C E$ reactions}

Reverse transcription of $3^{\prime}$-RACE reactions was carried out as above, but with $5^{\prime}$-AAGCTTCCCGGGATCCGAATTC(T) ${ }_{14}$ as primer. Three rounds of nested PCR were carried out, all using the same downstream primer 5'-AAGCTTCCCGGGATCCGAATTC. Five $\mu \mathrm{l}$ of the RT reaction and a genespecific primer I (5'-CTTCAAGGCGCTCAAGCAAT for Ginmyc1 and 5'-AGACGTGGATCAATCCCACT for Ginhb1) as upstream primer was used for the first round PCR. $0.1 \mu \mathrm{l}$ of this reaction was used as template for the round $2 \mathrm{PCR}$, using a nested gene-specific primer $2\left(5^{\prime}\right.$-TGACGCCTTAGAAACCTACA for Ginmyc1 and 5'-CTCTGAGAATGCACTCTACT for Ginhb1) as upstream primer. This was repeated for a third round with gene-specific primer 3 (5'-CTCCGAGAAGACCATCAATA for Ginmyc1 and 5'-GGCTACCAACAAGGGTCATA for Ginhb1). Cycling conditions were as described above for genome of origin PCR. Amplification products were separated on agarose gels, candidate bands cut from the gel and subcloned into pZero for sequencing.

\section{RNA slot blots and hybridization}

Approx. 150 ng of mRNA were blotted onto nylon membrane (Hybond- $\mathrm{N}^{+}$, Amersham) using a Bio-Dot SF microfiltration apparatus (BioRad). Before blotting, the mRNA was denatured in a buffer containing $6 \times$ SSC and $7.2 \%$ formaldehyde. After blotting, the membrane was air dried and the RNA uv crosslinked to the membrane (GS GeneLinker, BioRad). Prehybridization and hybridization were carried out in $6 \times$ SSC $/ 10 \times$ Denhardt's $/ 2 \%$ SDS $/ 100 \mathrm{ug} \mathrm{ml}^{-1}$ salmon sperm DNA for $4-6 \mathrm{~h}$ (prehybridization) and overnight (hybridization) at $65^{\circ}$ in a hybridization oven (Ratek Instruments, Australia). Probes were labelled with $\left[\alpha^{-32} \mathrm{P}\right] \mathrm{dCTP}$. After hybridization, membranes were washed several times for $10 \mathrm{~min}$ each in $2 \times \mathrm{SSC} / 0.1 \% \mathrm{SDS}$ at $65^{\circ}$ and $2 \times 15 \mathrm{~min}$ in $0.1 \times \mathrm{SSC} / 0.1 \% \mathrm{SDS}$ at $65^{\circ}$.

\section{RESULTS}

\section{Colonization of barley in nurse pots}

Establishment of a VA mycorrhizal symbiosis is a reproducibly timed developmental process, but the long-term compatible interaction means that in plants inoculated by conventional methods all stages occur simultaneously, which is a disadvantage for molecular studies. To obtain barley roots with rapid, synchronous and high levels of colonization by Glomus intraradices, we used the nurse pot system described for tomato (Rosewarne et al., 1997), in which colonization of the target plant (barley) occurs from symbiotic external hyphae growing from the nurse plant (leek). The synchronous staging of colonization of barley roots in nurse pots was essentially the same as that of tomato colonized by the same fungus. Arbuscules were first visible at about 5-6 days after transplanting (d.a.t.) barley seedlings into the nurse pots and vesicles could first be observed at about 6-7 d.a.t. At 10 d.a.t. barley roots had $55 \%$ of the root length colonized. Nonmycorrhizal barley was grown in the same way, but with nonmycorrhizal leeks in the nurse pots.

\section{Identification of differentially accumulated transcripts using differential display PCR}

RNA for the initial differential display PCR was isolated from mycorrhizal and non-mycorrhizal barley roots at 5 d.a.t., when about $15 \%$ root length was colonized and few arbuscules had yet been formed. Fungal biomass in the roots was therefore very low. Poly $\left(\mathrm{A}^{+}\right)$RNA was reverse transcribed with random primers and differential display PCR was subsequently performed with unlabelled nucleotides. The PCR products were separated on agarose gels containing ethidium bromide (Sokolov \& Prockop, 1994). Using random primers for reverse transcription increases the probability that fragments obtained by the differential display PCR will be derived from the coding regions of the cDNAs, thus providing more information about the putative proteins they encode. 


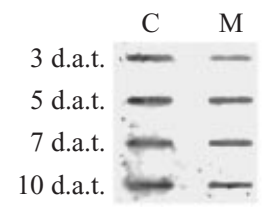

$d d 1 A$

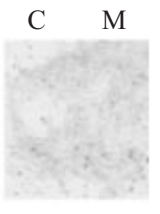

Ginmyc1

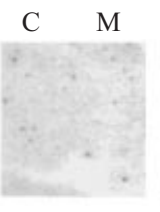

Ginmyc2

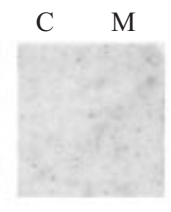

Ginhb1
Fig. 1. Slot blot mRNA analysis of $d d 1 A$ (barley beta-tubulin) and fungal fragments Ginmyc1, Ginmyc2 and Ginhb1. mRNA was isolated from mycorrhizal (M) or non-mycorrhizal control (C) barley roots at 3, 5, 7 and $10 \mathrm{~d}$ after transplanting barley seedlings into nurse pots. Approx. $150 \mathrm{ng}$ of mRNA was loaded per slot. Membranes were hybridized with radioactively labelled probes for dd1A, Ginmyc1, Ginmyc2 and Ginhb1 as indicated.

The number of bands obtained depended on the primer used. Some primers gave only a few very strong bands that were equally strong in all lanes, whereas others produced about 25 visible bands, some of which were consistently different between mycorrhizal and non-mycorrhizal samples. The largest fragments obtained were about 2000 bp long, with the majority of bands falling between 100 and $1000 \mathrm{bp}$.

Of 20 bands that were cut from differential display gels, 17 were successfully cloned. Of these, four were derived from uncolonized control roots in the differential display PCR, 13 were isolated from mycorrhizal roots. To confirm which of the differential display bands corresponded to moderately abundant or abundant transcripts that were differentially accumulated in mycorrhizal roots, we hybridized the cloned fragments to slot blots of poly $\left(\mathrm{A}^{+}\right)$RNA from mycorrhizal and nonmycorrhizal barley roots extracted 3, 5, 7 and 10 d.a.t. Approx. $150 \mathrm{ng}$ poly $\left(\mathrm{A}^{+}\right) \mathrm{RNA}$ were loaded to each slot. Assuming that $0.6 \%$ of total root RNA consists of mRNA (Cox \& Goldberg, 1988), this would correspond to $25 \mu \mathrm{g}$ of total RNA. Of the 17 fragments analysed in this way, two gave differential hybridization signals, eight showed no difference, and seven gave no signal at all (Fig. I and data not shown). One of the fragments $(d d 1 A)$ that was derived from uncolonized control roots in the differential display PCR and gave a uniform hybridization signal was identical in sequence to a barley beta-tubulin (GenBank accession no. Y09741). Because it gave an equally uniform signal as an rDNA probe on blots of total RNA (data not shown), it was chosen as loading control on slot blots of mRNA. Fig. I shows the hybridization of $d d 1 A$ and three of the seven 'undetectable' clones, which were all derived from mycorrhizal roots, to slot blots of mRNA.

Others have also observed that cDNAs isolated by differential display sometimes fail to detect RNAs on northern blots (Mason \& Davis, 1997). In our study the most likely explanation is related to the different sensitivities of the two methods. Differential display enables the cloning of mRNAs that are present at abundance levels below the detection limit of our RNA slot blot hybridization analysis. In symbiotic roots fungal RNAs would certainly fall into the low abundance category, especially at early time points of colonization, when the contribution of fungal biomass to the total biomass of the mycorrhizal root would be low and fungal mRNAs diluted by plant mRNAs (Franken et al., 1997). Of the seven differential

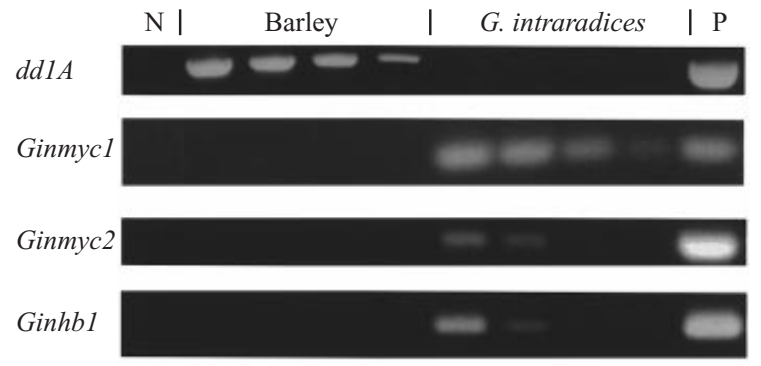

Fig. 2. PCR for genome of origin. PCR products were amplified from genomic DNA using primer pairs specific for $d d 1 A$, Ginmyc1, Ginmyc2 and Ginhb1 and analysed by agarose gel electrophoresis. Sizes of the amplified products were: $458 \mathrm{bp}$ for $d d 1 A, 267 \mathrm{bp}$ for Ginmyc1, 413 bp for Ginmyc2 and 251 bp for Ginhb1. N: negative control without template DNA, $\mathrm{P}$ : positive control with cDNA clone as template. Barley: templates were $500 \mathrm{ng}$ to $4 \mathrm{ng}$ genomic barley leaf DNA in five-fold dilution steps. G. intraradices: successive fivefold dilutions of genomic DNA isolated from G. intraradices spores; amounts were adjusted to include equivalent sequence molarities as the barley reactions, based on nuclear DNA content of G. intraradices spores (Bianciotto \& Bonfante, 1992) and genome analysis of barley (Arumuganathan \& Earle, 1991). [Note: Feint bands in the third lane from the right occur in the lower two strips.]

display fragments that gave no signal on the slot blots, two were derived from uncolonized control roots in the differential display PCR, thus presumably being of plant origin, whereas the other five (among them Ginmyc1, Ginmyc2 and Ginhb1) were derived from mycorrhizal roots. These could either be of plant origin, representing genes that are expressed below the detection limit of the slot blot hybridizations, or they could represent fungal genes. Because of this second possibility we retained them for further analysis.

\section{Three differential display fragments are of fungal origin and are expressed during symbiosis}

Sequence analysis of the differential display fragments enabled the design of specific PCR primer pairs. These primers were used to determine if the differential display fragments represent plant or fungal genes by performing PCR on genomic DNA from barley and G. intraradices. As can be seen in Fig. 2, primers for $d d 1 A$ gave amplification products of the expected size only with barley DNA as template. Primers for Ginmyc1, Ginmyc2 and Ginhb1 gave products only with DNA from G. intraradices. For all four differential display fragments, the amplification products from genomic DNA have the same sizes as the products from the cloned cDNAs, indicating that no introns are present in the amplified regions.

As the fungal differential display fragments did not give signals when used as probes on RNA slot blots, we performed RT-PCR with the fragment-specific primer pairs on poly $\left(\mathrm{A}^{+}\right)$ RNA from 5 d.a.t. mycorrhizal and non-mycorrhizal barley roots, to confirm that the corresponding genes were expressed in the symbiotic association. Fig. 3 shows the results of this experiment. Transcripts corresponding to $d d 1 A$ accumulated both in mycorrhizal and uncolonized roots, confirming its plant genome origin. The primers for the fungal clones gave rise to amplification products of the expected sizes only with RNA from roots colonized by $G$. intraradices. Control reactions 


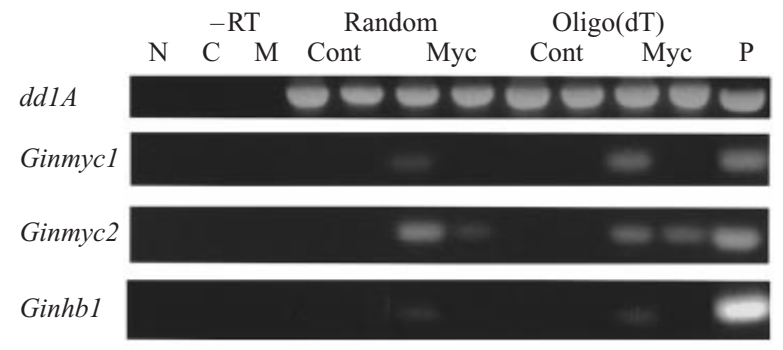

Fig. 3. RT-PCR for expression of the genes corresponding to $d d 1 A$, Ginmyc1, Ginmyc2 and Ginhb1 in barley roots. PCR products were obtained from amplification of root mRNA without $(-\mathrm{RT})$ or with reverse transcription and analysed by agarose gel electrophoresis. mRNA was extracted from barley roots 5 d.a.t. to mycorrhizal (M, Myc) or non-mycorrhizal (C, Cont) nurse pots. Random: reverse transcription with random primers. Oligo(dT): reverse transcription with oligo(dT). N: negative control without template. P: positive control with cDNA clone as template. Cont, Myc: two dilutions of the respective RT reactions as templates. Sizes of amplified fragments were the same as in Fig. 2. [Note: A feint band occurs in the sixth lane from the right in the lower strip.]

using poly $\left(\mathrm{A}^{+}\right) \mathrm{RNA}$ without reverse transcription as template served to show that the PCR products were not derived from DNA contaminations in the RNA preparations. RNA was extracted from colonized roots that were thoroughly washed and had only a small amount of external mycelium attached. The plants were colonized by symbiotic hyphae growing from the leek 'nurse plants' and no spores were observed during assessment of colonization, so that all the fungal material was highly likely to be 'symbiotic'. Thus, we concluded that the genes corresponding to Ginmyc1, Ginmyc2 and Ginhb1 were fungal genes expressed during growth of $G$. intraradices in association with barley roots, but we cannot at this stage conclude whether expression is in internal or external hyphae or both.

\section{Ginmyc1, Ginmyc2 and Ginhb1 potentially encode regulatory proteins}

The original clones Ginmyc1 and Ginhb1 were respectively 317 and $1290 \mathrm{bp}$ in length, whilst Ginmyc2 was $858 \mathrm{bp}$. We used 3'-RACE to extend the sequences of Ginmyc1 and Ginhb1 to 1475 and $1532 \mathrm{bp}$ respectively (to the $3^{\prime}$ ends of the corresponding cDNAs). Each of the three sequences contained a clearly identifiable ORF. Since all three cDNAs are partial at their $5^{\prime}$ end, the start codons of the putative proteins are not present. Starting at the $5^{\prime}$ end of the fragment, Ginmyc 1 and Ginhb1 contain uninterrupted reading frames of 370 and 458 amino acids respectively. These are terminated by stop codons and followed by 332 (Ginmyc1) and 154 bp (Ginhb1) of $3^{\prime}$ untranslated sequence. Ginmyc2 contains a continuous uninterrupted reading frame of 286 amino acids. We performed a database search with the deduced amino acid sequences of the protein coding regions using BlastP on protein data bases at GenomNet (Tokyo Center), in order to identify potential functions for each represented gene. GINMYC1 showed similarity to a group of proteins that are conserved between a wide range of organisms. Fig. 4 shows the alignment of the deduced amino acid sequence of Ginmyc1 with corresponding regions of three of these sequences: the Drosophila protein Alien (Goubeaud et al., 1996; 45\% protein identity); the human protein TRIP15 (Lee et al., 1995; partial cDNA sequence ORF, $46 \%$ protein identity); and a Ricinus communis partial cDNA sequence ORF (van de Loo, Turner \& Somerville, 1995).

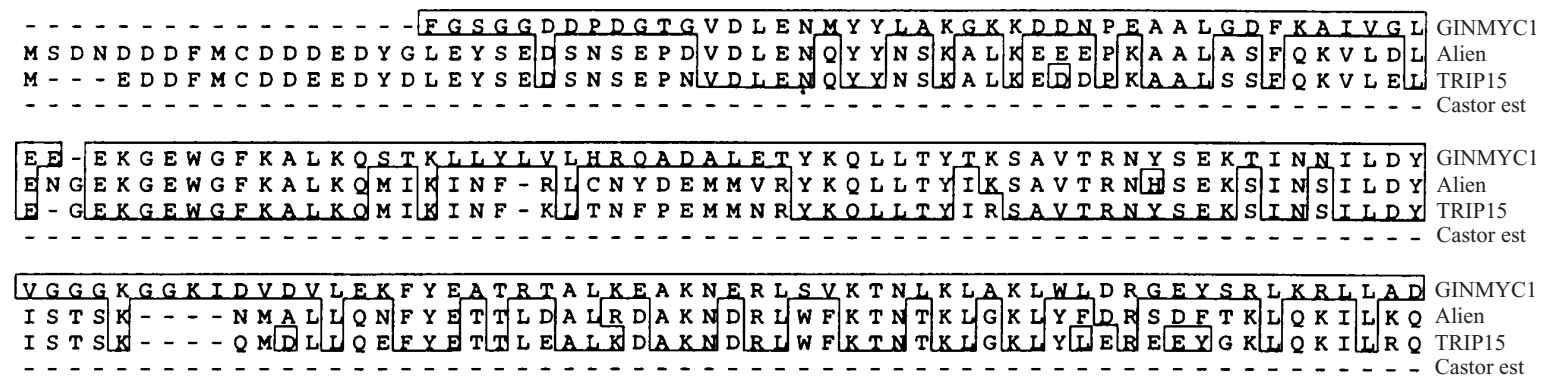

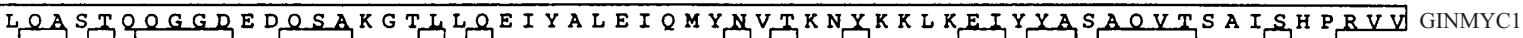

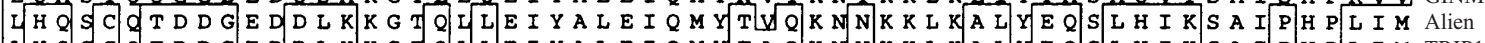

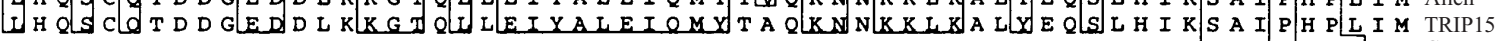

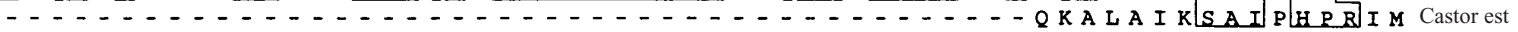

GVIKECG G KIVDAKKKOWEAKRLKD F FSSFHN Y D EAGS PQRIQVLKYLVLAYLL MGSEID GINMYC1

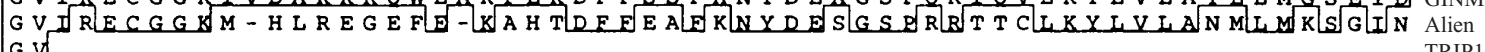
GV

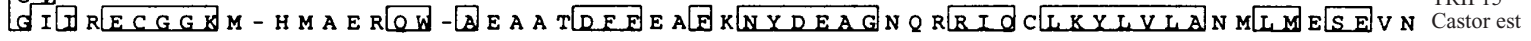

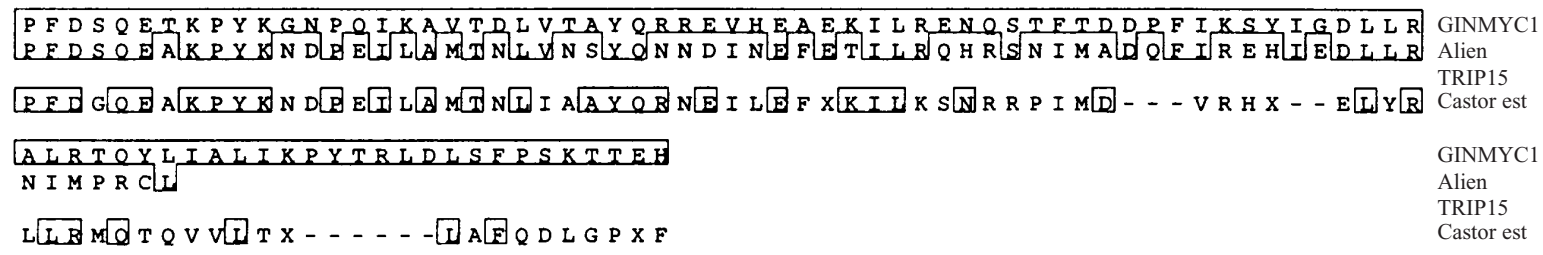

Fig. 4. Alignment of the deduced amino acid sequence of Ginmyc1 with Alien from Drosophila, TRIP15 from humans (partial cDNA sequence ORF, N-terminal region) and Ricinus communis (Castorest) (partial cDNA sequence ORF, C-terminal region). Positions identical to GINMYCI are boxed. 


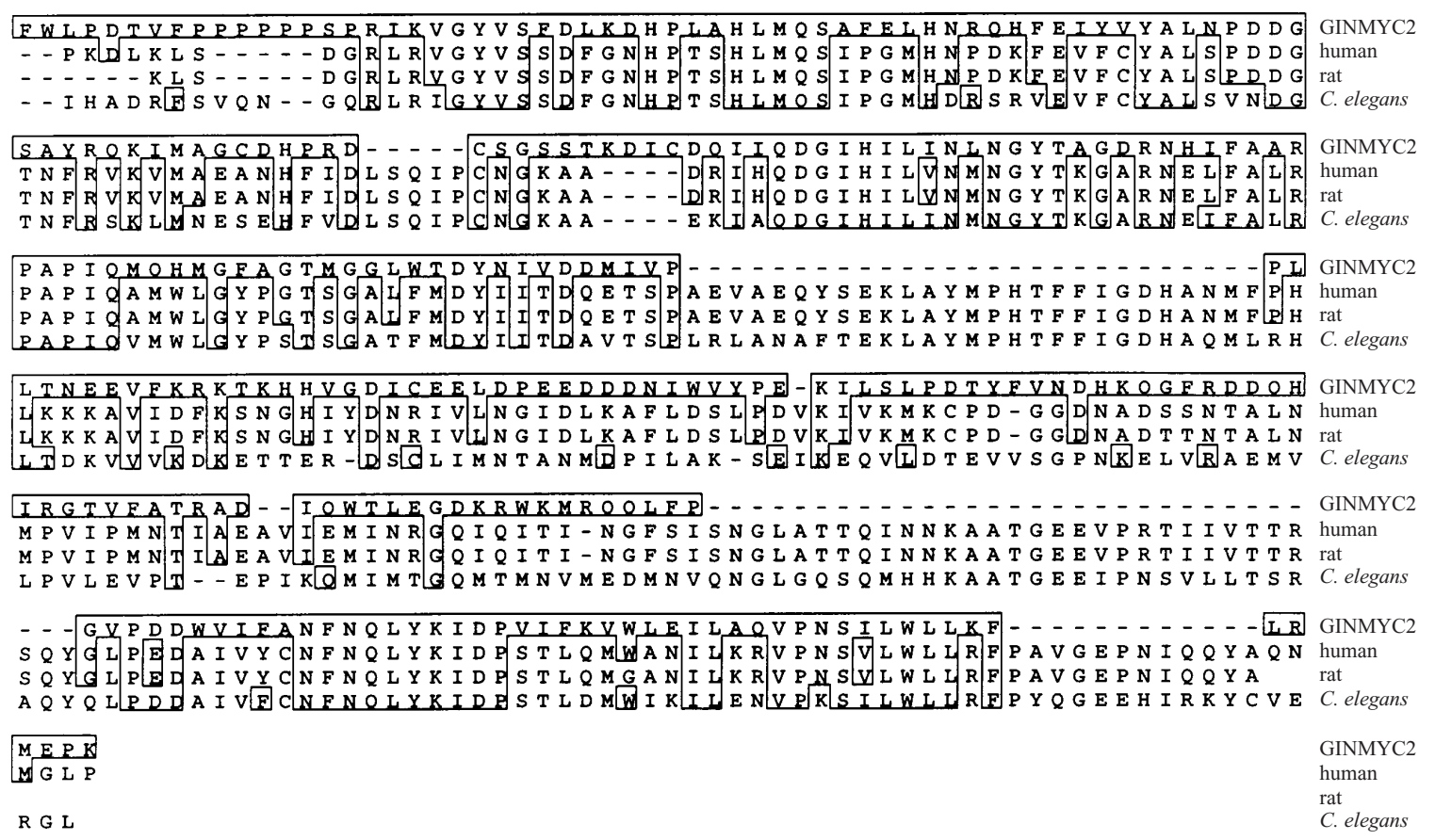

Fig. 5. Alignment of the deduced amino acid sequence of Ginmyc2 with O-GlcNAc transferases from human, rat and C. elegans. Positions identical to GINMYC2 are boxed.

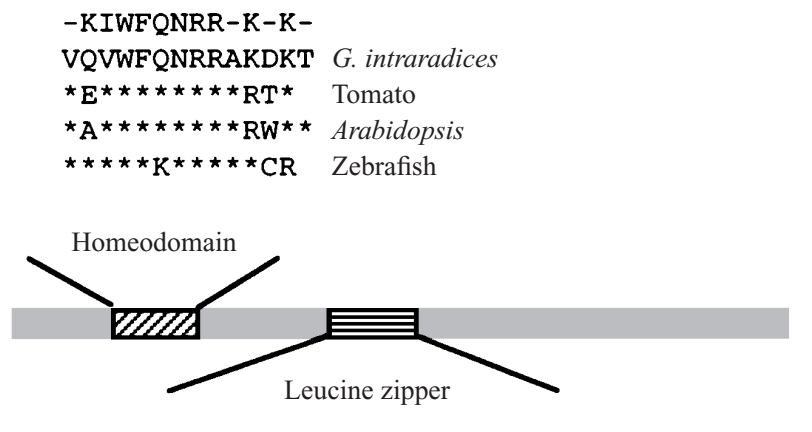

...GPLKPPSIPLRIPETCLVPAGLSLTF. . .

Fig. 6. Schematic representation of the features of GINHBI. The homeodomain sequence of GINHBI from $G$. intraradices is shown above the corresponding sequences of tomato, Arabidopsis and zebrafish proteins (accession nos S76820, X58821 and D26173 respectively). Stars indicate amino acids identical to GINHB1. Above the $G$. intraradices homeodomain, the most highly conserved amino acid positions from an alignment of the homeodomains of 83 proteins from higher eukaryotes (Scott, Tamkun \& Hartzell, 1990) are given. The sequence of the putative leucine zipper of GINHBI is shown with the leucine repeats in bold.

Fig. 5 shows the alignment of GINMYC2 with corresponding regions of three members of a group of protein sequences that function as $\mathrm{O}$-linked $\mathrm{N}$-acetylglucosamine transferases (Lubas et al., 1997; Kreppel, Blomberg \& Hart, 1997). These are the only proteins that show significant similarity to GINMYC2. The highest identity is with the human sequence $(33 \%$ amino acid identity in the aligned region). A significant feature of this group of proteins is the presence of a 34 amino acid repeated sequence motif, termed a tetratricopeptide repeat, in the N-terminal region of the proteins. Whether GINMYC2 also contains a tetratricopeptide repeat structure was not determined, because the deduced amino acid sequence of the partial cDNA did not extend far enough into the N-terminal region of the protein.

Sequence analysis of the deduced amino acid sequence of Ginhb1 revealed that it contained a homeodomain (HD) as a putative DNA-binding region and a leucine zipper as a potential protein interaction site (Fig. 6). Outside of the homeodomain there was no significant identity of GINHBI to other proteins.

\section{DISCUSSION}

Our objective in this research was to identify fungal genes that are expressed early in establishment of the symbiosis and that might, therefore, play an integral role in communication with the plant host. To accomplish this, we successfully adopted a 'nurse-pot' colonization procedure previously used for VA mycorrhizal research on tomato, that results in rapid synchronous and abundant colonization (Rosewarne et al., 1997). At all time points percent of the root length colonized in barley was consistently lower than in tomato. The highest colonization was observed 10 d.a.t. and was $55 \%$ of root length for barley compared to $80 \%$ for tomato. The difference is probably due to the different rates of root growth in the nurse pots, which was consistently rapid for barley, whereas tomato roots grew only very little during the same time period (Rosewarne et al., 1997). Identification of three fungal partial cDNAs potentially coding for proteins with regulatory functions indicates that this relatively simple colonization method is useful for developmental analysis of the symbiosis in plants with differing root growth patterns.

This paper reports one of the first successful attempts to apply a non-targetted approach, differential display PCR, to 
isolate genes that are expressed in the vegetative stages of VA mycorrhizal symbiosis. The use of a non-radioactive amplification and separation of products by agarose gel electrophoresis has advantages over the more commonly used radiolabelling method, including the fact that technical difficulties in handling and cloning the amplified products are reduced (Sokolov \& Prockop, 1994; see also Delp et al., 1998). In this obligate symbiosis fungal biomass is low, relative to plant biomass, making it time-consuming to obtain large amounts of genetic material and difficult to detect mRNAs of fungal origin (Fig. 1). Use of differential display to identify differentially expressed genes combined with PCR amplification of genomic DNA from fungal spores (Fig. 2) and RTPCR analysis of fungal gene expression (Fig. 3), has overcome this problem of 'dilution' of fungal RNAs in total RNA from plant roots.

Sequence alignment of the deduced amino acid sequence of Ginmyc1 with protein sequences in databases (Fig. 4) reveals that it has significant identity with Alien from Drosophila, a protein that is expressed in a developmentally regulated manner in muscle attachment sites during embryogenesis (Goubeaud et al., 1996), and TRIP15 from humans (Lee et al., 1995). TRIP15 was isolated with the yeast two hybrid system as a protein that interacts in a hormone-dependent manner with the thyroid receptor. Both alien and Trip15 encode highly conserved corepressors for nuclear hormone receptors (Dressel et al., submitted). Homologous sequences have also been described from a variety of organisms, including plants (Ricinus communis; partial cDNA with unknown function; van de Loo et al., 1995), Caenorhabditis elegans (partial cDNAs). The recent determination of steroid hormone function in plants (Szekeres et al., 1995) and the highly conserved nature of this protein between organisms together suggest that GINMYCI might be the Zygomycete homologue of an archetypal regulatory protein involved in intracellular hormonal signalling.

Our clone of Ginmyc2 is a partial cDNA that has similarity to the C-terminal part of $\mathrm{O}$-linked $\mathrm{N}$-acetylglucosamine transferases (OGTs; Fig. 5). Full length cDNA sequences coding for OGTs have been cloned from humans, Caenorhabditis elegans and rat. OGTs seem to consist of two domains: the N-terminal region containing a tetratricopeptide repeat (TPR) motive that is common to a diverse group of proteins, and a C-terminal region, which could contain the catalytic activity and does not show significant homology to other proteins (Kreppel et al., 1997). The enzyme from rat is a heterotrimer consisting of two catalytic units of $110 \mathrm{kDa}$, plus a $78 \mathrm{dKa}$ subunit (Haltiwanger, Blomberg \& Hart, 1992). GINMYC2 shows identity to the catalytic subunit (Fig. 5). OGTs add a single $\mathrm{N}$-acetylglucosamine in $\mathrm{O}$-glycosidic linkage to serine or threonine residues in cytosolic and nuclear proteins. This glycosylation does not occur in the endomembrane system, as for other glycosylation reactions. The glycosylation is reversible and is thought to regulate protein function similarly to phosphorylation (Hart, 1997). TPRs are thought to confer intra- and intermolecular protein-protein interactions and may also be involved in targetting the proteins to their intracellular destinations. OGTs are conserved over a wide evolutionary spectrum. There are expressed sequence tags from organisms as far apart as Schistosoma mansoni and rice with similarity to OGT.

GINHBI contains a homeodomain (HD), a DNA-binding motif that is highly conserved between a large number of transcriptional regulators from both animals and plants. The second motif that can be detected in GINHBI is a leucine zipper, a periodic repetition of leucine residues at every seventh position. This sequence organization is thought to confer protein-protein interaction in eucaryotic gene regulatory proteins. The combination of $\mathrm{HD}$ and leucine zipper in a single gene has previously been described only for plants (Schena \& Davis, 1992; Mattsson et al., 1992; Sessa, Morelli \& Ruberti, 1997), although a huge number of HD proteins have been identified in animals. In HD-Zip proteins from plants the leucine zipper is tightly linked to the HD, whereas in GINHBI the two motifs are spaced 110 amino acids apart. This has not been observed before. Furthermore, although HD proteins have been described from fungi and include the mating-type genes from basidiomycetes (Casselton \& Olesnicky, 1998), these do not contain a leucine zipper motif. Interestingly, the proteins encoded by mating-type genes heterodimerise on mating, thus generating an active transcriptional regulator. Based on its similarity to other $\mathrm{HD}$ proteins we predict that GINHBI may have similar function.

Comparison of the results of research from several laboratories suggests that the complexity of genes expressed in establishment of the symbiosis is significant, as there has been minimal overlap to date in identity of the transcripts described, either from plants or fungi (Barker et al., 1998). The three fungal genes we have isolated all have potentially regulatory functions. The next important steps will be to obtain full length clones, which will allow more precise comparisons with other genes, and determine their expression patterns at different stages of fungal development. It will be important to include presymbiotic phases (spores, germinating spores), and different stages of the development of symbiosis with plants (appressorium, internal colonization etc.). The recent report of transformation of a VA mycorrhizal fungus (Forbes et al., 1998) is an important technical advance that will enable our speculation about the functional role of these genes to be tested. Once genes that are involved in communication between the symbiotic partners are identified, it will be possible to examine their potential for developing novel mechanisms of resistance in crop plants to biotrophic root parasites.

\section{ACKNOWLEDGEMENTS}

We want to thank the Nucleic Acid and Protein Chemistry Unit at the Waite Institute for performing the DNA sequencing and M. Lynch and U. Theopold for help with the RNA slot blot hybridizations. Funding through the ARC Special Research Centre for Basic and Applied Plant Molecular Biology is gratefully acknowledged.

\section{REFERENCES}

Arumuganathan, K. \& Earle, E. (1991). Nuclear DNA content of some important plant species. Plant Molecular Biology Reporter 9, 208-218.

Barker, S. J., Tagu, D. \& Delp, G. (1998). Regulation of root and fungal morphogenesis in mycorrhizal symbioses. Plant Physiology 116, 1201-1207. 
Bauer, D., Müller, H., Reich, J., Riedel, H., Ahrenkiel, V., Warthoe, P. \& Strauss, M. (1993). Identification of differentially expressed mRNA species by an improved display technique (DDRT-PCR). Nucleic Acids Research 21, $4272-4280$.

Bécard, G. \& Fortin, J. A. (1988). Early events of vesicular-arbuscular mycorrhiza formation of Ri T-DNA transformed roots. New Phytologist 108, 211-218.

Bianciotto, V. \& Bonfante, P. (1992). Quantification of the nuclear DNA content of two arbuscular mycorrhizal fungi. Mycological Research 96, 1071-1076.

Burleigh, S. \& Harrison, M. (1998). A cDNA from the arbuscular mycorrhizal fungus Glomus versiforme with homology to a cruciform DNA-binding protein from Ustilago maydis. Mycorrhiza 7, 301-306.

Casselton, L. \& Olesnicky, N. (1998). Molecular genetics of mating recognition in basidiomycete fungi. Microbiology \& Molecular Biology Reviews 62, 55-70.

Cox, K. \& Goldberg, R. B. (1988). Analysis of plant gene expression. In Plant Molecular Biology: A Practical Approach (ed. C. Shaw), pp. 1-36. IRL Press: Oxford, U.K.

Delp, G., Rosewarne, G. M. \& Barker, S. J., (1998). The molecular route to understanding VAM symbiosis. In Mycorrhiza Manual (ed. A. Varma), pp. 327-352. Springer-Verlag: Berlin, Heidelberg, Germany.

Forbes, P. J., Millam, S., Hooker, J. E. \& Harrier, L. A. (1998). Transformation of the arbuscular mycorrhiza Gigaspora rosea by particle bombardment. Mycological Research 102, 497-501.

Franken, P., Lapopin, L., Meyer-Gauen, G. \& Gianinazzi-Pearson, V. (1997). RNA accumulation and genes expressed in spores of the arbuscular mycorrhizal fungus, Gigaspora rosea. Mycologia 89, 293-297.

Giovannetti, M. \& Mosse, B. (1980). An evaluation of techniques for measuring vesicular-arbuscular mycorrhizal infection in roots. New Phytologist 84, 489-500.

Goubeaud, A., Knirr, S., Renkawitz-Pohl, R. \& Paululat, A. (1996). The Drosophila gene alien is expressed in the muscle attachment sites during embryogenesis and encodes a protein highly conserved between plants. Drosophila and vertebrates. Mechanisms of Development 57, 59-68.

Haltiwanger, R. S., Blomberg, M. A. \& Hart, G. W. (1993). Glycosylation of nuclear and cytoplasmic proteins. Journal of Biological Chemistry 267, 9005-9013.

Harrison, M. J. (1997). The arbuscular mycorrhizal symbiosis. In Plant-Microbe Interactions (ed. G. Stacey \& N. T. Keen), pp. 1-34. Chapman \& Hall: London.

Harrison, M. J. \& van Buuren, M. L. (1995). A phosphate transporter from the mycorrhizal fungus Glomus versiforme. Nature 378, 626-629.

Hart, G.W. (1997). Dynamic O-linked glycosylation of nuclear and cytosceletal proteins. Annual Review of Biochemistry 66, 315-335.

Kaldorf, M., Schmelzer, E. \& Bothe, H. (1998). Expression of maize and fungal nitrate reductase genes in arbuscular mycorrhiza. Molecular Plant Microbe Interactions 11, 439-448.

Kreppel, L. K., Blomberg, M. A. \& Hart, G. W. (1997). Dynamic glycosylation of nuclear and cytosolic proteins. The Journal of Biological Chemistry 272, 9308-9315.

Lee, J. W., Choi, H.S., Gyuris, J., Brent, R. \& Moore, D. D. (1995). Two classes of proteins dependent on either the presence or absence of thyroid hormone for interaction with the thyroid hormone receptor. Molecular Endocrinology 9, 243-254.

Liang, P. \& Pardee, A. B. (1992). Differential display of eukaryotic messenger RNA by means of the polymerase chain reaction. Science 25 7, 967-970.

Lubas, W. A., Frank, D. W., Krause, M. \& Hanover, J. A. (1997). O-linked GlcNAc transferase is a conserved nucleocytoplasmic protein containing tetratricopeptide repeats. The Journal of Biological Chemistry 272, 9316-9324.
Martin-Laurent, F., Franken, P. \& Gianinazzi, S. (1995). Screening of cDNA fragments generated by differential RNA display. Analytical Biochemistry 228, 182-184.

Martin-Laurent, F., Van Tuinen, D., Dumas-Gaudot, E., Gianinazzi-Pearson, V., Gianinazzi, S. \& Franken, P. (1997). Differential display analysis of RNA accumulation in arbuscular mycorrhiza of pea and isolation of a novel symbiosis-regulated plant gene. Molecular \& General Genetics 256, 37-44.

Mason, M. E. \& Davis, J. M. (1997). Defense response in slash pine: Chitosan treatment alters the abundance of specific mRNAs. Molecular Plant Microbe Interctions 10, 135-137.

Mattsson, J. Söderman, E., Svenson, M., Borkird, C. \& Engström, P. (1992). A new homeobox-leucine zipper gene from Arabidopsis thaliana. Plant Molecular Biology 18, 1019-1022.

Phillips, J. M. \& Hayman, D. S. (1970). Improved procedures for clearing roots and staining parasitic and vesicular-arbuscular mycorrhizal fungi for rapid assessment of infection. Transactions of the British Mycological Society 55, $158-160$.

Remy, W., Taylor, T. N., Hass, H. \& Kerp, H. (1994). Four hundred-millionyear-old vesicular-arbuscular mycorrhizae. Proceedings of the National Academy of Sciences U.S.A. 91, 11841-11843.

Rogowsky, P., Guidet, F., Langridge, P., Shepherd, K. \& Koebner, R. (1991). Isolation and characterization of wheat-rye recombinants involving chromosome arm IDS of wheat. Theoretical and Applied Genetics 82, 537-544.

Rosewarne, G. M., Barker, S. J. \& Smith, S. E. (1997). Production of nearsynchronous fungal colonization in tomato for developmental and molecular analyses of mycorrhiza. Mycological Research 101, 966-970.

Sambrook, J., Fritsch, E. F. \& Maniatis, T. (1989). Molecular Cloning : a Laboratory Manual. Cold Spring Harbor Laboratory Press: New York, U.S.A.

Schena, M. \& Davis, R. W. (1992). HD-Zip proteins: members of an Arabidopsis homeodomain protein superfamily. Proceedings of the National Academy of Sciences U.S.A. 89, 3894-3898.

Scott, M. P., Tamkun, J. W. \& Hartzell, G. W. (1990). The structure and function of the homeodomain. Biochimica and Biophysica Acta 989, 25-48.

Sessa, G., Morelli, G. \& Ruberti, I. (1997). DNA-binding specificity of the homeodomain leucine zipper domain. Journal of Molecular Biology 274, 303-309.

Simon, L., Bousquet, J., Levesque, R. C. \& Lalonde, M. (1993). Origin and diversification of endomycorrhizal fungi and coincidence with vascular land plants. Nature 363, 67-69.

Smith, S. E. \& Read, D. J. (1997). Mycorrhizal Symbiosis. Academic Press: London, U.K.

Sokolov, B. P. \& Prockop, D. J. (1994). A rapid and simple PCR-based method for isolation of cDNAs from differentially expressed genes. Nucleic Acids Research 22, 4009-4015.

Szekeres, M., Németh, K., Koncz-Kálmán, Z., Mathur, J., Kauschmann, A., Altmann, T., Rédei, G. P., Nagy, F., Schell, J. \& Koncz, C. (1995). Brassinosteroids rescue the deficiency of CYP90, a cytochrome P450, controlling cell elongation and de-etiolation in Arabidopsis. Cell 85, 171-182.

van de Loo, F. J., Turner, S. \& Somerville, C. (1995). Expressed sequence tags from developing castor seeds. Plant Physiology 108, 1141-1150.

Vögeli-Lange, R., Bürckert, N., Boller, T. \& Wiemken, A. (1996). Rapid selection and classification of positive clones generated by mRNA differential display. Nucleic Acids Research 24, 1385-1386.

Wan, J. S., Sharp, S. J., Poirier, G. M.-C., Wagaman, P. C., Chambers, J., Pyati, J., Hom, Y.-L., Galindo, J. E., Huvar, A., Peterson, P. A., Jackson, M. R. \& Erlander, M. G. (1996). Cloning differentially expressed mRNAs. Nature Biotechnology 14, 1685-1691.

Zézé, A., Dulieu, H. \& Gianinazzi-Pearson, V. (1994). DNA cloning and screening of a partial genomic library from an arbuscular mycorrhizal fungus, Scutellospora castanea. Mycorrhiza 4, 251-254. 